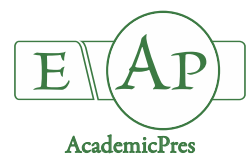

\title{
Mycorrhiza Regulates Signal Substance Levels and Pathogen Defense Gene Expression to Resist Citrus Canker
}

\author{
Miao-Miao XIE ${ }^{1}$, Yi-Can ZHANG ${ }^{1}$, Li-Ping LIU ${ }^{1}$, Ying-Ning ZOU ${ }^{1 *}$, \\ Qiang-Sheng WU ${ }^{1,2 *}$, Kamil KUČA ${ }^{2}$ \\ 'Yangtze University, College of Horticulture and Gardening,Jingzhou, Hubei 434025, China; 972948575@qq.com; zhangyic1992@163.com; \\ llp31302@163.com; zouyingning@163.com (*correspondingauthor); wuqiangsh@163.com ("corresponding author) \\ ${ }^{2}$ University of Hradec Kralove, Faculty of Science, Department of Chemistry, Hradec Kralove 50003, Czech Republic; kamil.kuca@ubk.cz
}

\begin{abstract}
Citrus canker is a quarantined disease, severely harming citrus plants. Soil beneficial arbuscular mycorrhizal fungi (AMF) can provide a biological control pathway to resist pathogens. This work was to test changes of signal substances including hydrogen peroxide $\left(\mathrm{H}_{2} \mathrm{O}_{2}\right)$, nitric oxide $(\mathrm{NO})$, calmodulin $(\mathrm{CaM})$, salicylic acid $(\mathrm{SA})$ and jasmonic acid (JA) and the pathogen defense gene expression in roots of AMF (Paraglomus occultum) and non-AMF trifoliate orange (Poncirus trifoliata) seedlings after infected by a expressions citrus canker pathogen (Xanthomonas axonopodis pv. Citri, Xac). AMF inoculation significantly improved plant height, stem diameter and leaf number. Xac infection dramatically decreased root $\mathrm{H}_{2} \mathrm{O}_{2}, \mathrm{NO}$, and SA levels, but increased root CaM and JA concentrations in non-AMF seedlings. There were higher $\mathrm{H}_{2} \mathrm{O}_{2}$ and CaM levels and lower JA levels in Xac-infected seedlings than in non-Xac-infected seedlings under mycorrhization. Under non-Xac infection, mycorrhizal treatment reduced root $\mathrm{H}_{2} \mathrm{O}_{2}, \mathrm{NO}$, and SA but increased CaM and JA levels. However, under Xac infection, mycorrhizal inoculation distinctly accelerated root $\mathrm{H}_{2} \mathrm{O}_{2}, \mathrm{NO}, \mathrm{CaM}$, and $\mathrm{SA}$ accumulation, accompanied with up-regulated expression levels of root PtEPSI (enhance pseudomonas susceptibility 1) and PtPR4 (pathogenesis related gene 4), indicating that Xac stimulated mycorrhizal roles in enhancing resistance of citrus canker. Such results imply that citrus plants with preinoculated AMF had stronger resistance to Xac infection through increasing signal substrate accumulation and pathogen defense gene expressions.
\end{abstract}

Keywords: arbuscular mycorrhizal fungi; canker; pathogenesis related gene; salicylic acid

\section{Introduction}

Citrus is the most popular fruit in China, where citrus planted area is the biggest (about $22 \%$ of total fruit areas) and the yield is account for $15 \%$ of total fruit yield in 2017. In open field, citrus plants are often subjected to various diseases and insect pests, whilst citrus canker caused by Xanthomonas axonopodis pv. citri (Xac) is a quarantined disease in the world, severely decreasing tree growth and fruit production (Das, 2003). Until now, there is no effective way to prevent the disease.

Arbuscular mycorrhizal (AM) fungi (AMF), a kind of soil beneficial microorganisms, establish the symbiotic association with roots to enhance biotic resistance of host plants including root-knot nematode, bacterioses and fungal disease (Liu et al., 2007; Nair et al., 2015; Sharma and Sharma, 2017; Wu et al., 2017). In plants, arbuscular mycorrhizas need carbohydrates and fatty acids of host plants to sustain fungal growth, and mycorrhizal symbiosis helps plants absorb water and nutrients (Wu et al., 2019). Oyewole et al. (2017) reported that inoculation with Glomus deserticola and Gigaspora gigantea exhibited inhibitive effects on charcoal rot disease of cowpea. Mycorrhizal cyclamen plants had higher resistance to Fusarium wilt and anthracnose disease (Maya and Matsubara, 2013). The inoculation with Glomus sp. MUCL 41833 strongly decreased leaf infection index of Phytophthora infestans, and also induced expressions of pathogenesis related genes (PR) PRI and PR2 in potato, indicating systemic resistance appeared in mycorrhizal seedlings (Gallou et al., 2011).

In fact, many signal substances such as nitric oxide (NO), hydrogen peroxide $\left(\mathrm{H}_{2} \mathrm{O}_{2}\right)$, salicylic acid (SA), and jasmonic acid (JA) are involved in system acquired resistance (SAR) formation by mycorrhizal induction and play an important role in increasing disease resistant. 
1162

Hypersensitive responses in plants are induced by pathogen infection accompanied with accumulation of $\mathrm{NO}$ and reactive oxygen species (ROS), which further induces the expression of defense genes and SAR establishment (Delledonne, 2005). In general, NO is increased in pathogen-infected plants (i.e., tobacco), and the NO peak is appear at 5 minutes after infecting by pathogen (Foissner $e t$ al., 2000). $\mathrm{H}_{2} \mathrm{O}_{2}$, a kind of ROS, plays an important role in defense gene expression, which can induce the expression of $P A L$ (phenylalnine ammonialyase) and CHS (chalcone synthase) (Neill et al., 2002; Zhang et al., 2013). Calcium iron $\left(\mathrm{Ca}^{2+}\right)$, a common signal molecule in plants to respond pathogen infection, has the capacity of the early immune reaction in cells to resist pathogen (DeFalco et al., 2010). Calmodulin (CaM) is one of the $\mathrm{Ca}^{2+}$ receptor, and $\mathrm{Ca} / \mathrm{CaM}$ activates many biochemical processes to enhance pathogen resistance (Kim et al., 2009). Exogenous application of SA helps pepper plants to resist blight by inducing the protein expression participating in defense systems (Chandrasekhar et al., 2017). The rice seedlings treated by exogenous methyl jasmonate owned the resistance for bacterial blight by up-regulating the expression of defense enzymes genes (Azami-Sardooei et al., 2010). These results demonstrate that many signalling substances are involved in the process of plant disease resistance, while it is not known how mycorrhiza-enhancing disease resistance of host plants is associated with changes of signalling substances and pathogen defense gene expression.

The present study tried to inoculate an AM fungus into trifoliate orange (Poncirus trifoliata L. Raf., a common rootstock of citrus used in Southeast Asia) and further illuminated the changes of signalling substance concentrations and pathogen defense gene expression after Xac infection.

\section{Materials and Methods}

\section{Experimental design}

The experiment was arranged in completely randomized blocked design with the inoculation with or without Paraglomus occultum (+AMF or -AMF) and the infection with or without Xanthomonas axonopodis pv. citri (+Xac or $-\mathrm{Xac}$ ), in total of four treatments. The four treatments were expressed as + AMF+Xac, $+\mathrm{AMF}-\mathrm{Xac},-\mathrm{AMF}+\mathrm{Xac}$, and AMF-Xac, respectively. Each treatment had four replications.

\section{Plant culture}

The seed of trifoliate orange was sterilized by $70 \%$ ethanol solutions, cleaned by $10 \% \mathrm{KOH}$ solutions to remove pectin, and germinated at sterilized $(0.11 \mathrm{MPa}, 121$ ${ }^{\circ} \mathrm{C}, 1 \mathrm{~h}$ ) sands. Three four-euphylla seedlings with same size were transplanted into 1.6-L plastic pots, in which $1.3 \mathrm{~kg}$ of sterilized mixture of soil and vermiculite $(5: 1, \mathrm{v} / \mathrm{v})$ was supplied. The seedlings were grown in a glasshouse, where day/night temperature was $25 / 19^{\circ} \mathrm{C}$, average air humidity $85 \%$, and photo flux density $721-967 \mu \mathrm{mol} / \mathrm{m}^{2} / \mathrm{s}$.

An AM fungus, Paraglomus occultum (Walker) Morton \& Redecker, was provided by the Bank of Glomeromycota in China and propagated by white clover (Trifolium repens) under potted conditions. The mycorrhizal inoculums included sands, spores and infected root segments, whilst the spore density was 12 spores/g inoculum. Xanthomonas axonopodis pv. citri (Xac) was provided by the National Center for Citrus Improvement (Changsha), China, and further propagated based on the protocol described by Liu et al. (2012).

At transplanting, the seedlings were inoculated with 120 g mycorrhizal inoculums (approx. 1500 spores) per pot, and non-AMF treatment was applied with $120 \mathrm{~g}$ sterilized substrates plus $3 \mathrm{~mL}$ inoculums filtrate $(25 \mu \mathrm{m}$ filter $)$ for similar microbial communities except spores of Paraglomus occultum. After 10 weeks of transplanting, the Xac was inoculated by needle puncturing method (Deng et al., 2010), and the fifth and sixth leaves on the top of seedlings were treated with $20 \mu \mathrm{L}\left(10^{8} \mathrm{CFU} / \mathrm{mL}\right)$ bacterial suspension. The Xac-treated wound was covered by filter paper $\left(0.78 \mathrm{~cm}^{3} /\right.$ piece). The bacterial suspension was replaced by sterilized distilled water in non-Xac treatment. After 5 days of Xac infection (water-soaked spot appeared), the seedlings were harvested.

\section{Variable determinations}

Before harvest, the plant height, stem diameter and leaf number were measured.

The $1-2 \mathrm{~cm}$ root segment was cleared by $10 \% \mathrm{KOH}$ at $90{ }^{\circ} \mathrm{C}$ and stained with $0.05 \%$ typan blue in lactophenol solutions (Philips and Hayman, 1970). The root mycorrhizal colonization was expressed as the percentage in the colonized root lengths versus total observed root lengths. The soil hyphae length was determined according to the protocol of Bethlenfalvay and Ames (1987).

The $0.2 \mathrm{~g}$ root samples were homogenized with 0.1 $\mathrm{mol} / \mathrm{L}$ phosphate buffer $(\mathrm{pH} 7.0)$ to assay the concentration of signal substrates, including SA, JA, NO, and CaM, as per the double antibody sandwich method. The measure was done according to user's handbook of kits which were produced by Shanghai Enzyme-linked Biotechnology Co., Ltd, China.

Root $\mathrm{H}_{2} \mathrm{O}_{2}$ was extracted by $10 \%$ trichloroacetic acid solutions and detected in the mixture of $1 \mathrm{~mL}$ supernatant, $1 \mathrm{~mL}$ potassium phosphate buffers, and $2 \mathrm{~mL}$ potassium iodide at $390 \mathrm{~nm}$ (Velikova et al., 2000).

Root RNA was extracted by the EASY Spin Plus RNA kit (RN38, Aidlab Biotechnologies CO. Ltd, China), and the reverse transcription was proceeded by the reverse transcription kit (RP047A, TAKARA). The qRT-PCR experiment was performed in the Bio-Rad CFX Connect Real-Time System (Bio-Rad Laboratories, Inc., US) with 10 $\mu \mathrm{L}$ system. The gene sequences used in the experiment were selected based on the RNA-seq data of trifoliate orange, and the primer sequence was shown in Table 1. Relative expression was calculated according to the method of Livak and Schmittgen (2001). Actin-7 was used as the reference gene.

\section{Statistical analysis}

Data (means $\pm \mathrm{SD}, n=4$ ) were analyzed with the ANOVA (SAS, version 8.1), and the significantly difference between treatments was compared by the Duncan's multiple range test at 0.05 levels. 
Table 1. The primer sequences of relevant genes involved in SA signaling in trifoliate orange

\begin{tabular}{ccc}
\hline \multirow{2}{*}{ Gene name } & & Primer sequence $\left(5^{\prime} \rightarrow 3^{\prime}\right)$ \\
\cline { 2 - 3 } & Forward primer & Reverse primer \\
\hline PtPAL & TCTTACGGCGTTACCACTG & TGACTCTGTTCCGTTCCA \\
$P t E P S 1$ & CAAGCGTGTAGCAACCAA & GCGTAAATGGACGGAGTG \\
PtPR4 & GCCGCAGAAGGCAGTCCA & TCCAATGTGAGGGCAACT \\
Actin-7 & CCGACCGTATGAGCAAGGAAA & TTCCTGTGGACAATGGATGGA \\
\hline
\end{tabular}

\section{Results}

\section{Plant growth}

As shown in Table 2, AMF colonization significant increased plant height and leaf number, but did not affect stem diameter, regardless of Xac infection or not. Xac treatment did not significantly alter plant growth performance, irrespective of AMF inoculation or not.

\section{Mycorrbizal colonization and soil hyphal length}

Root mycorrhizal colonization ranged from $26.9 \%$ under + AMF-Xac conditions to $27.2 \%$ under $+\mathrm{AMF}+\mathrm{Xac}$ conditions, and soil hyphal length was 26.2 $\mathrm{cm} / \mathrm{g}$ under $+\mathrm{AMF}+\mathrm{Xac}$ conditions to $25.7 \mathrm{~cm} / \mathrm{g}$ under + AMF-Xac conditions (Fig. 1). Xac infection did not alter root mycorrhizal colonization and soil hyphal length.

\section{Root $\mathrm{H}_{2} \mathrm{O}_{2}$ concentrations}

Under non-Xac infection conditions, AMF inoculation significantly decreased root $\mathrm{H}_{2} \mathrm{O}_{2}$ levels by $36 \%$, whereas increased it by $74 \%$ in the present of Xac, compared with non-AMF treatment (Fig. 2). Compared with infection without Xac, Xac infection affected root $\mathrm{H}_{2} \mathrm{O}_{2}$ concentrations: decrease it by $27 \%$ in non-AMF plants and increase it by $97 \%$ in AMF plants.

\section{Root NO concentrations}

As shown in Fig. 3, both Xac infection and AMF inoculation influenced root $\mathrm{NO}$ concentrations. AMF treatment reduced root $\mathrm{NO}$ concentrations by $37 \%$ under non-Xac conditions but increased it by $65 \%$ under Xac infection condition. In addition, root $\mathrm{NO}$ concentrations were decreased by Xac infection in the absence of AMF.

\section{Root CaM concentrations}

AMF inoculation and Xac infection both significantly increased root $\mathrm{CaM}$ contents (Fig. 4). Root CaM concentrations were increased by mycorrhizal inoculation: $216 \%$ and $148 \%$ higher under non-Xac and Xac infection conditions, respectively. Xac infection also increased root $\mathrm{CaM}$ contents, and the increment was $88 \%$ higher in nonAMF plants and $47 \%$ higher in AMF plants.

\section{Root JA concentrations}

Root JA concentrations were ranked as +AMF-Xac > $\mathrm{AMF}+\mathrm{Xac} \approx+\mathrm{AMF}+\mathrm{Xac}>-\mathrm{AMF}-\mathrm{Xac}$ in the decreased order (Fig. 5). Inoculation with AMF significantly increase root JA concentrations under non -Xac conditions. Xac infection significantly increased root JA concentrations under non-AMF conditions but significantly decreased root JA concentrations under +AMF conditions.

Table 2. The effect of Paraglomus occultum and Xanthomonas axonopodis pv. citri on plant growth of trifoliate orange seedlings

\begin{tabular}{|c|c|c|c|}
\hline Treatments & Plant height $(\mathrm{cm})$ & Stem diameter $(\mathrm{mm})$ & Leaf number (\#/plant) \\
\hline -AMF-Xac & $20.60 \pm 0.94 b$ & $2.25 \pm 0.07 \mathrm{a}$ & $20 \pm 2 b$ \\
\hline+ AMF-Xac & $25.32 \pm 1.55 \mathrm{a}$ & $2.29 \pm 0.14 \mathrm{a}$ & $23 \pm 1 \mathrm{a}$ \\
\hline$-\mathrm{AMF}+\mathrm{Xac}$ & $21.18 \pm 1.68 \mathrm{~b}$ & $2.24 \pm 0.08 \mathrm{a}$ & $21 \pm 2 b$ \\
\hline$+\mathrm{AMF}+\mathrm{Xac}$ & $24.78 \pm 2.81 \mathrm{a}$ & $2.27 \pm 0.19 \mathrm{a}$ & $24 \pm 1 \mathrm{a}$ \\
\hline
\end{tabular}
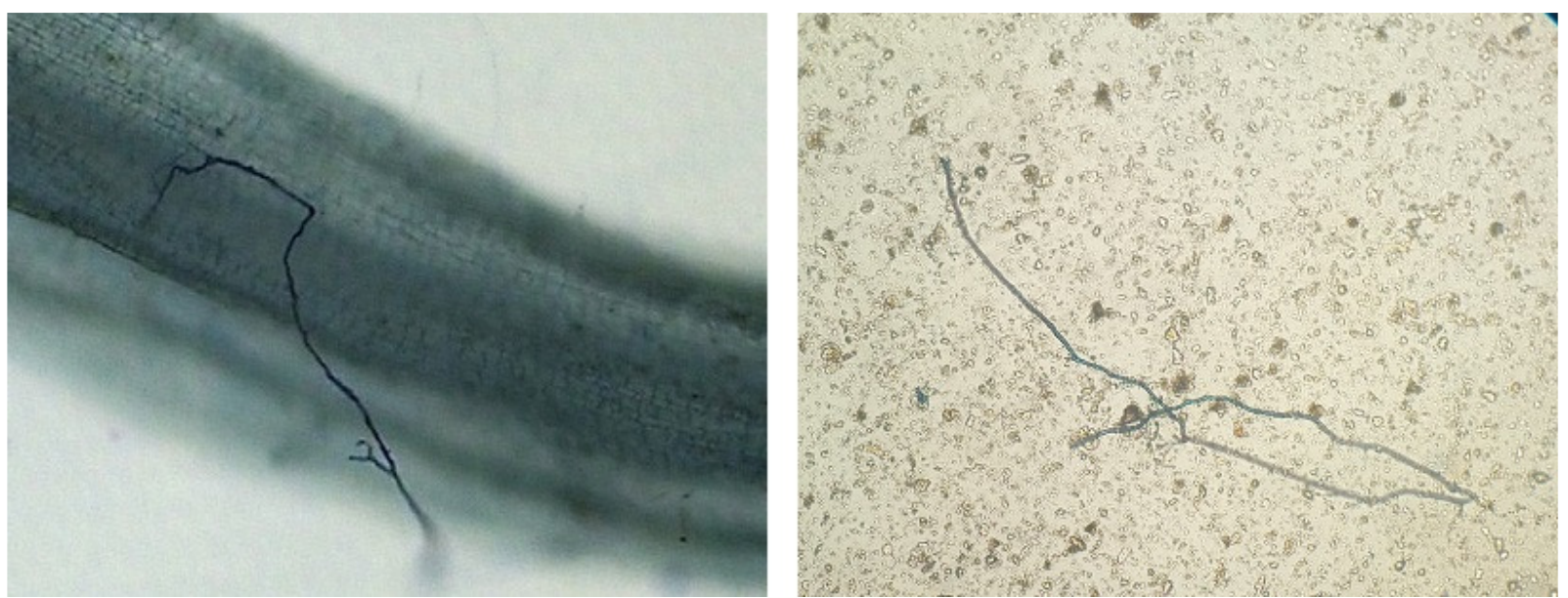

Fig. 1. The extraradical hyphae (left) and soil hyphae (right) of Paraglomus occultum in trifoliate orange seedlings 


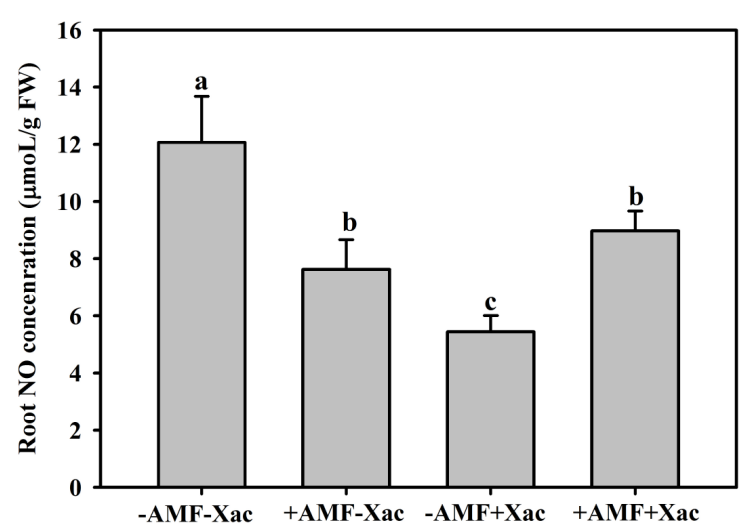

Fig. 2. The effect of Paraglomus occultum and Xanthomonas axonopodis pv. citri on root $\mathrm{H}_{2} \mathrm{O}_{2}$ concentrations in trifoliate orange seedlings. Data (means $\pm \mathrm{SD}, n=4$ ) with different letter at the bar indicated the significant difference among treatments at 0.05 levels
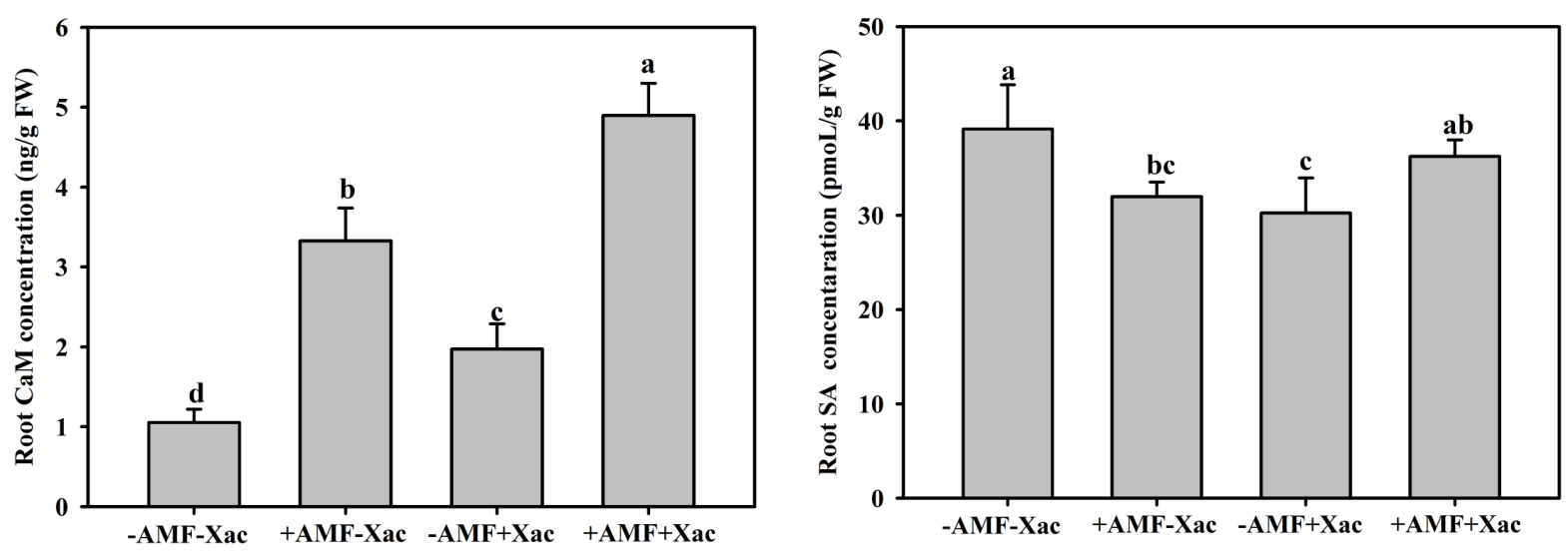

Fig. 4. The effect of Paraglomus occultum and Xanthomonas axonopodis pv. citri on root $\mathrm{CaM}$ concentrations in trifoliate orange seedlings. Data (means $\pm \mathrm{SD}, n=4$ ) with different letter at the bar indicated the significant difference among treatments at 0.05 levels

\section{Root SA concentrations}

AMF inoculation markedly decreased root SA concentrations by $18 \%$ in the case of non-Xac infection while increased root SA concentrations by $20 \%$ in the case of $\mathrm{Xac}$ infection (Fig. 6). In addition, Xac infection decreased $\mathrm{SA}$ concentrations in $-\mathrm{AMF}+\mathrm{Xac}$ treatment, compared with -AMF-Xac treatment.

\section{Relative expression of pathogen defense genes in roots}

Xac inoculation significantly decreased the expression of PtPAL in roots regardless of inoculation with or without AMF, while AMF inoculation had no effect on PtPAL

Fig. 3. The effect of Paraglomus occultum and Xanthomonas axonopodis pv. citri on root $\mathrm{NO}$ concentrations in trifoliate orange seedlings. Data (means $\pm \mathrm{SD}, n=4$ ) with different letter at the bar indicated the difference was significant among treatments at 0.05 levels

Fig. 5. The effect of Paraglomus occultum and Xanthomonas axonopodis pv. citri on root JA concentrations in trifoliate orange seedlings. Data (means $\pm \mathrm{SD}, n=4$ ) with different letter at the bar indicated the significant difference among treatments at 0.05 levels

expression under $-\mathrm{Xac}$ or $+\mathrm{Xac}$ conditions (Fig. 7). AMF and Xac inoculation had significant effects on PtEPSI expression in roots. AMF inoculation significantly decreased PtEPS1 expression in roots by $25 \%$ under $-\mathrm{Xac}$ conditions but increased it by $46 \%$ under + Xac conditions (Fig. 7). Xac infection also decreased root PtEPS1 expression in the case of non-AMF inoculation. There were higher expression levels of PtPR4 in +AMF treatment versus -AMF treatment, regardless of Xac infection or not (Fig. 7). Meanwhile, the PtPR4 expression in roots was distinctly increased in $+\mathrm{AMF}+\mathrm{Xac}$ treatment, as compared with +AMF-Xac treatment. 


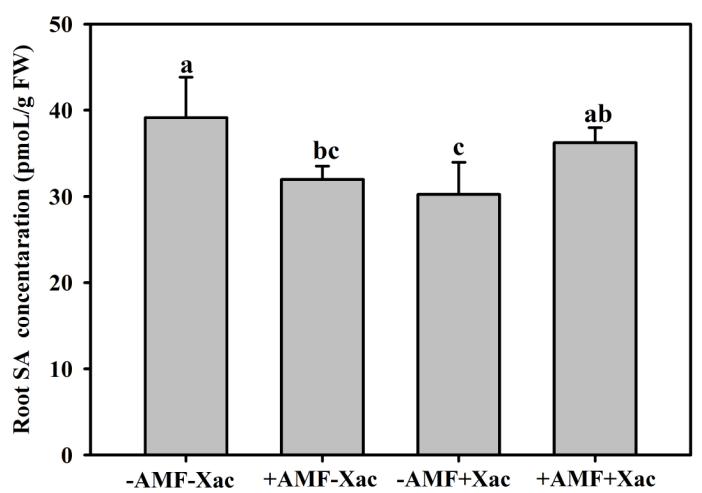

Fig. 6. The effect of Paraglomus occultum and Xanthomonas axonopodis pv. citri on root SA concentrations in trifoliate orange seedlings. Data (means $\pm \mathrm{SD}, n=4$ ) with different letter at the bar indicated the significant difference among treatments at 0.05 levels

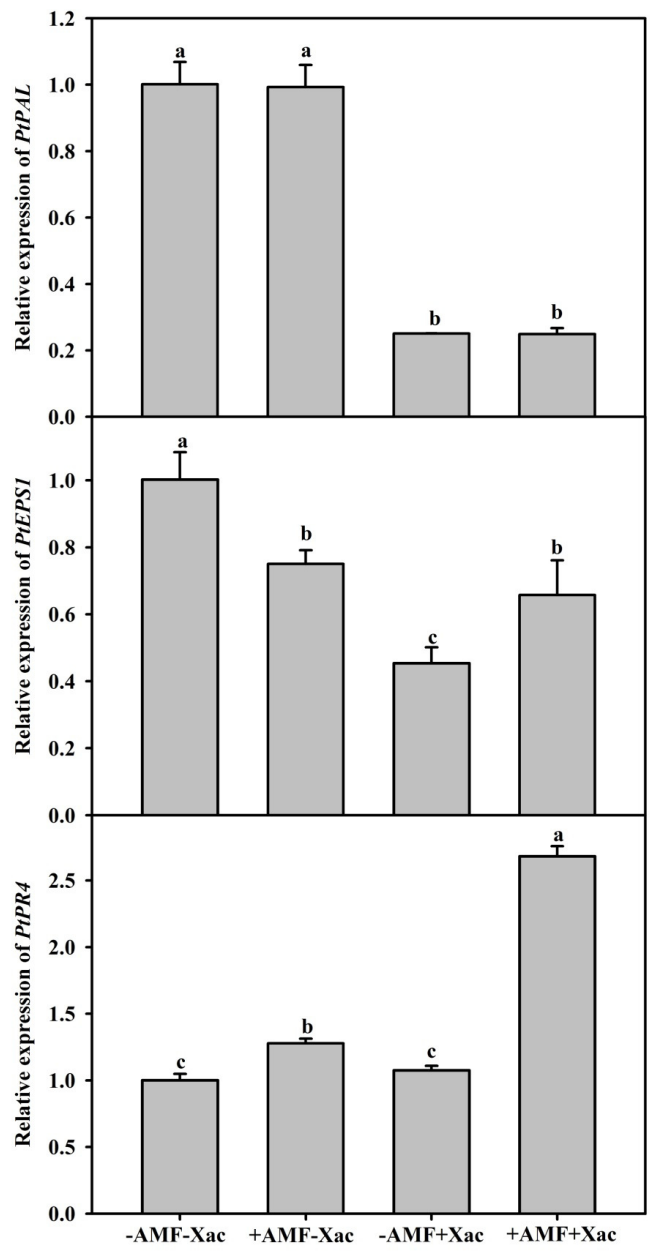

Fig. 7. The effect of Paraglomus occultum and Xanthomonas axonopodis pv. citri on relative expression of root PtPAL, PtEPS1, and PtPR4 genes in trifoliate orange seedlings. Data (means $\pm \mathrm{SD}, n=3$ ) with different letter at the bar indicated the significant difference among treatments at 0.05 levels

\section{Discussion}

The present study indicated a positive effect of AMF inoculation on plant growth of trifoliate orange, which also had been proved in various host plants such as Metrosideros laurifolia (Amie et al., 2019), maize (Ghorchiani et al., 2018), tea (Shao et al., 2018) and tomato (Vani et al., 2018). The Xac infection had no effect on plant growth of trifoliate orange and root mycorrhizal colonization, the possible reason of which was short-term time for the Xac infection (5 days), not enough to cause any responses of plant growth and mycorrhizas.

It is documented that $\mathrm{H}_{2} \mathrm{O}_{2}$ takes part in earliest defense responses to pathogen and also enhances the rigidity of structural proteins in cell walls to prevent pathogen infection (Lamb and Dixon, 1997; Grant and Loake, 2000). On the other hand, $\mathrm{H}_{2} \mathrm{O}_{2}$ can active expression of chitinases, peroxidases and lignin (Wu et al., 1997). Mohase et al. (2011) showed that there were higher $\mathrm{H}_{2} \mathrm{O}_{2}$ levels in resistant sunflower plants to resist rust. In our work, root $\mathrm{H}_{2} \mathrm{O}_{2}$ levels were the highest under $+\mathrm{AMF}+\mathrm{Xac}$ treatment conditions, indicating that the trifoliate orange seedlings induced stronger resistance. In addition, mycorrhizal plants recorded significantly higher root $\mathrm{H}_{2} \mathrm{O}_{2}$ levels than nonmycorrhizal plants under +Xac infection conditions, meaning that SAR has been formed in the AMF seedlings, and AMF accelerates $\mathrm{H}_{2} \mathrm{O}_{2}$ accumulation to tolerate Xac infection. However, compared with - AMF-Xac treatment, the $\mathrm{H}_{2} \mathrm{O}_{2}$ levels were decreased in $+\mathrm{AMF}-\mathrm{Xac}$ treatment, based on the fact of which non-Xac plants did not need such $\mathrm{H}_{2} \mathrm{O}_{2}$ response and mycorrhizas accelerate root $\mathrm{H}_{2} \mathrm{O}_{2}$ effluxes into rhizosphere (Zou et al., 2015).

In our work, AMF inoculation under -Xac conditions and $\mathrm{Xac}$ infection under non-mycorrhization collectively decreased root NO concentrations, the reason of which may be the fact that sole microorganism inoculation induces lower root NO levels, or the NO peak is missed (Zhang et al., 2017a). Nevertheless, under Xac infection, AMF inoculation significantly increased root $\mathrm{NO}$ levels, as compared with non-AMF treatment, indicating that mycorrhizas stimulate root NO accumulation under Xac infection. More NO may be used to modify proteins to perform various functions in defense responses (Lindermayr et al., 2005).

Zhang et al. (2010) found the CaM binding protein CBP60g induced the expression of SA synthetic gene ICSI and further activated SA biosynthesis and defense response. Hence, $\mathrm{CaM}$ is pivotal for activating downstream defense response. It is known that AMF inoculation could enhance the expression of $\mathrm{CaM}$ in host plants exposed to abiotic stress, such as drought stress (Huang et al., 2014). The mycorrhizal soybean showed higher CaM concentrations to capture signals (Lorella et al., 2007). In this work, AMF inoculation and Xac infection collectively increased root CaM concentrations of trifoliate orange, indicating that the CaM-signal pathway had been activated by Xac infection and AMF inoculation to reinforce the effect. AMF plants represented higher root $\mathrm{CaM}$ levels than non-AMF plants under Xac or non-Xac infection conditions, implies that mycorrhizas further strengthen the CaM-signal pathway to respond Xac infection by inducing more 'signal receiver'. 
1166

There are SA and JA pathways to transfer signals in plants, and SA and JA pathways exhibit synergistic effects at low concentrations but antagonistic at high concentrations (Spoel and Dong, 2008). Compared with -AMF-Xac treatment, +AMF-Xac treatment significantly increased root JA contents and the expression of PtPR4, while decreased root $S A$ contents and relative expression of PtEPS1, indicating that without Xac infection, mycorrhizal plants depend JA and PtPR4 to enhance resistance. The result is consistent with previous study in which AMF inoculation primed disease resistance of tomato to resist early blight disease (Song et al., 2015). The expression of PtPR4 was not changed by $\mathrm{Xac}$ infection in nonmycorrhizal plants but significantly increased in proinoculated AMF plants, indicating that primed mycorrhizal plants are easier to deal with the Xac infection.

In our previous studies, JA and SA concentrations were significantly increased when suberification was formed in the Xac-infected site (Zhang et al., 2017b, 2019). However, in this work, only the JA content was increased when water stain appeared in Xac-treated plants. Hence, we speculated that SA and JA play different roles during Xac infection. Nair et al. (2015) inoculated AMF and Fusarium oxysporum on tomato and found that JA took part in the expression of resistance and SA induced defense responses. In early stage of pathogen infection, JA could thicken cell wall, induce defense substrates (proteinase, PAL and LOX) synthesis, and oxygen burst to enhance resistance (Azami-Sardooei $e t$ al., 2010). However, SA may work in prolonged response ageing. More works in JA and SA responses need to be done under mycorrhization and Xac infection.

\section{Acknowledgements}

This study was supported by the Plan in Scientific and Technological Innovation Team of Outstanding Young Scientists, Hubei Provincial Department of Education (T201604).

\section{Conflict of Interest}

The authors declare that there are no conflicts of interest related to this article.

\section{References}

Amir H, Cavaloc Y, Laurent A (2019). Arbuscular mycorrhizal fungi and sewage sludge enhance growth and adaptation of Metrosideros laurifolia on ultramafic soil in New Caledonia: A field experiment. Science of the Total Environment 651(1):334343.

Azami-Sardooei Z, Franca SC, De Vlesschauwer D, Höfte M (2010). Riboflavin induces resistance against Botrytis cinerea in bean, but not in tomato, by priming for a hydrogen peroxide-fueled resistance response. Physiological and Molecular Plant Pathology75(1-2):23-29.

Bethlenfalvay GJ, Ames RN (1987). Comparison of two methods for quantifying extraradical mycelium of vesicular arbuscular mycorrhizal fungi. Soil Science Society of America Journal 51(3):834-837.
Chandrasekhar B, Umesha S, Naveen Kumar HN (2017). Proteominc analysis of salicylic acid enhanced disease resistance in bacterial wilt affected chili (Capsicum annuum) crop. Physiological and Molecular Plant Pathology 98:85-96.

Das AK (2003). Citrus canker - A review. Journal of Applied Horticulture 5(1):52-60.

DeFalco TA, Bender KW, Snedden WA (2010). Breaking the code: $\mathrm{Ca}^{2+}$ sensors in plant signaling. Biochemical Journal 425(1):27-40.

Delledonne M (2005). NO news is good news for plant. Current Opinion in Plant Biology 8(4):390-396.

Deng ZN, Xu L, Long GY, Liu LP, Fang FF, Shu GP (2010). Screening citrus genotypes for resistance to canker disease (Xanthomonas axonopodis pv.citri). Plant Breeding 129(3):341-345.

Foissner I, Wendehenne D, Langebartels C, Durner J (2000). In vivo imaging of an elicitor-induced nitric oxide burst in tobacco. Plant Journal 23(6):817-824.

Gallou A, Mosquera HPL, Cranenbrouck S, Suárez JP, Declerck S (2017). Mycorrhiza induced resistance in potato plantlets challenged by Phytophthora infestans. Physiological and Molecular Plant Pathology 76(1):20-26.

Ghorchiani M, Etesami H, Alikhani HA (2018). Improvement of growth and yield of maize under water stress by co-inoculating an arbuscular mycorrhizal fungus and a plant growth promoting rhizobacterium together with phosphate fertilizers. Agriculture Ecosystems and Environment 258:59-70.

Grant, JJ, Loake, GJ (2000). Role of reactive oxygen intermediates and cognate redox signalingin disease resistance. Plant Physiology 124(1):2129.

Huang YM, Srivastava AK, Zou YN, Ni QD, Han Y, Wu QS (2014). Mycorrhizal-induced calmodulin mediated changes in antioxidant enzymes and growth response of drought-stressed trifoliate orange. Frontiers in Microbiology 5(682):1-7.

Kim MC, Chung WS, Yun DJ, Cho MJ (2009). Calcium and calmodulinmediated regulation of gene expression in plants. Molecular Plant 2(1):13-21.

Lamb C, Dixon RA (1997). The oxidative burst in plant disease resistance. Annual Review of Plant Physiology and Plant Molecular Biology 48(1):251-275.

Lindermayr J, Saalbach G, Durner J (2005). Proteomic identification of Snitrisylated proteins in Arabidopsis. Plant Physiology 137(3):921-930.

Liu JY, Maldonado-Mendoza L, Lopez-Meyer M, Cheung F, Town CD, Harrison MJ (2007). Arbuscular mycorrhizal symbiosis is accompanied by local and systemic alterations in gene expression and an increase in disease resistance in the shoots. Plant Journal 50(3):529-544.

Liu LP, Deng ZN, Qu JW, Yan JW, Catara V, Li DZ, Long GY, Li N (2012). Construction of EGFP-labeling system for visualizing the infection process of Xanthomonas axonopodis pv. citriinplanta. Current Microbiology 65(3):304312.

Livak LJ, Schmittgen TD (2001). Analysis of relative gene expression data using real-time quantitative PCR and $2^{-\Delta \Delta G}$ method. Methods 25(4):402-408. 
Lorella N, Moscatiello R, Genre A, Novero M, Bonfante P, Mariani P (2007). The arbuscular mycorrhizal fungus Glomus intraradices induces intracellular calcium changes in soybean cells. Caryologia 60(1-2):137140.

Maya MA, Matsubara YI (2013). Tolerance to Fusarium wilt and anthracnose diseases and changes of antioxidative activity in mycorrhizal cyclamen. Crop Protection 47(5):41-48.

Mohase L, der Westhuizen AJ, Pretorius ZA (2011). Involvement of reactive oxygen species generating enzymes and hydrogen peroxide in the rust resistance response of sunflower (Helianthus annuus L.). South African Journal of Plant and Soil 28(1):64-68.

Nair A, Kolet SP, Thilasiram HV, Bhargava S (2015). Systemic jasmonic acid modulation in mycorrhizal tomato plants and its role in induced resistance against Alternaria alternate. Plant Biology 17(3):625-631.

Nair A, Kolet SP, Thulasiram HV, Bhargava S (2105). Role of methyl jasmonate in the expression of mycorrhizal induced resistance against Fusarium oxysporum in tomato plants. Physiological and Molecular Plant Pathology 92:139-145.

Neill SJ, Desikan R, Clarke A, Hurst RD, Hancock JT (2002). Hydrogen peroxide and nitric oxide as signalling molecules in plants. Journal of Experimental Botany 53(372):1237-1247.

Oyewole BO, Olawuyi OJ, Odebode AC, Abiala MA (2017). Influence of arbuscular mycorrhiza fungi (AMF) on drought tolerance and charcoal rot disease of cowpea. Biotechnology Reports 14:8-15.

Parniske M (2008). Arbuscular mycorrhiza: the mother of plant root endosymbioses. Nature Reviews Microbiology 6(10):763-775.

Phillips JM, Hayman DS (1970). Improved procedures for clearing roots and staining parasitic and vesicular-arbuscular mycorrhizal fungi for rapid assessment of infection. Transactions of the British Mycological Society 55(1):158-161.

Romero-Puertas MC, Perazzolli M, Zago E, Delledonne M (2004). Nitric oxide signaling functions in plant interaction. Cellular Microbiology 6(9):795-803.

Shao YD, Zhang DJ, Hu XC, Wu QS, Jiang CJ, Xia TJ, Gao XB, Kuča K (2018). Mycorrhiza-induced changes in root growth and nutrient absorption of tea plants. Plant Soil and Environment 64(6):283-289.

Sharma IP, Sharma AK (2017). Co-inoculation of tomato with an arbuscular mycorrhizal fungus improves plant immunity and reduces root-knot nematode. Rhizosphere 4:25-28.

Song YY, Chen DM, Lu K, Sun ZX, Zeng R (2015). Enhances tomato disease resistance primed by arbuscular mycorrhizal fungus. Frontiers in PlantScience 6(786):1-13.
Spoel SH, Dong X (2008). Making sense of hormone crosstalk during plant immune response. Cell Host Microbe 3(6):348-351.

Vani MS, Hindumathi A, Reddy BN (2018). Beneficial effect of arbuscular mycorrhizal fungus, Glomus fasciculatum, on plant growth and nutrient uptake in tomato. Indian Phytopathology 71(1):115-122.

Velikova V, Yordanov I, Edreva A (2000). Oxidative stress and some antioxidant systems in acid rain-treated bean plants: protection of exogenous polyamines. Plant Science 15(1):59-66.

Wu G, Shortt BJ, Lawrence EB, Leo J, Fitzsimmons KC, Levine EB, Raskin I, Shah DM (1997). Activation of host defense mechanisms by elevated production of $\mathrm{H}_{2} \mathrm{O}_{2}$ in transgenic plants. Plant Physiology 115(2):427435.

Wu QS, He JD, Srivastava AK, Zou YN, Kuca K (2019). Mycorrhizas enhance drought tolerance of citrus by altering root fatty acid compositions and their saturation levels. Tree Physiology 39(7):11491158.

Wu QS, Sun P, Srivastava AK (2017). AMF diversity in citrus rhizosphere. Indian Journal of Agricultural Sciences 87(5):653-656.

Zhang RQ, Zhu HH, Zhao HQ, Yao Q (2013). Arbuscular mycorrhizal fungal inoculation increases phenolic synthesis in clover roots via hydrogen peroxide, salicylic acid and nitric oxide signaling pathways. Journal of Plant Physiology 170(1):7479.

Zhang Y, Xu S, DingP, WangDM, Cheng YT, HeJ, ... Zhang YL(2010). Control of salicylic acid synthesis and systemic acquired resistance by two members of a plant-specific family of transcription factors. Proceedings of the National Academy of Sciences 107(42):18220-18225.

Zhang YC, Liu CY, Wu QS (2017a). Mycorrhizal and common mycorrhizal network regulated the production of signal substances in trifoliate orange (Poncirus trifoliata). Notulae Botanicae Horti Agrobotanici Cluj-Napoca 45(1):43-49.

Zhang YC, Liu LP, Zou YN, Liu CY, Wu QS (2017b). Response of signal substances to canker in trifoliate orange roots through mycorrhizal hyphal bridge. Mycosystema 36(7):1028-1036 (in Chinese with an Engish abstract).

Zhang YC, Zou YN, Liu LP, Wu QS (2019). Common mycorrhizal networks activated salicylic acid defense response of trifoliate orange (Poncirus trifoliata). Journal of Integrative Plant Biology 61(10):10991111.

Zou YN, Huang YM, Wu QS, He XH (2015). Mycorrhiza-induced lower oxidative burst is related with higher antioxidant enzyme activities, net $\mathrm{H}_{2} \mathrm{O}_{2}$ effluxes, and $\mathrm{Ca}^{2+}$ influxes in trifoliate orange roots under drought stress. Mycorrhiza 25(2):143-152. 